\begin{tabular}{c} 
International Journal of Engineering \& Technology, $7(4.38)(2018) 856-860$ \\
International Journal of Engineering \& Technology \\
WPC \\
Website: www.sciencepubco.com/index.php/IJET \\
Research paper \\
\hline
\end{tabular}

\title{
How long are The Survival Time in the Industrial Sector of Indonesian Companies?
}

\author{
Farida Titik Kristanti*1, Deannes Isynuwardhana ${ }^{2}$ \\ ${ }^{I}$ Departement of Accounting, Faculty of Economics \& Business Telkom University, Bandung, West Java, Indonesia \\ ${ }^{2}$ Departement of Accounting, Faculty of Economics \& Business Telkom University, Bandung, West Java, Indonesia \\ *Corresponding author E-mail: faridatk@telkomuniversity.ac.id
}

\begin{abstract}
Cox Hazard model with time independent covariates is used to view the functions of survival and hazard for each group of industrial sector of companies listed on the Indonesia Stock Exchange. The hazard explains whether events of financial distress will occur in companies that have survived for a certain period. The survival function shows the relationship between probabilities to survive and time, in which time indicates the duration of an event (financial distress). The results of statistical analysis show that the survival time for each industrial group varies from 10.5 to 12.5 years. The results can be used as a basic idea for companies to determine when the preventive actions should be conducted so that companies will sustain their business.
\end{abstract}

Keywords: Survival; Industry Sector; Hazard; Survival

\section{Introduction}

The total cost of bankruptcy either directly or indirectly is about $15 \%$ of the company's value of an industry and about $7 \%$ for retailers before they experience financial distress [2] . In addition to these economic costs, bankruptcy also has social impacts on parties involved in a company including their family [5].The economic costs and social impacts arising from these bankrupt companies generate companies to have good identification before they go bankrupt. Early identification of potential failure of the companies will be able to provide early indications of problems that exist within the company so that correction can be taken on decisionmaking of the companies.

Bankruptcy can be classified into two categories through qualitative approach and quantitative approach [9]. A study using a qualitative approach was [5] which extensively analyzed the causes and symptoms of company failure through a number of books and articles, as well as interviews with a number of experts of the company failure. Another category is through a quantitative approach done by using statistical methods and explanatory variables Static Model fails to predict the failure of a company effectively [9] because the static model cannot control each period of the companies at risk due to long duration of study period. It is, therefore, very important to control over the fact that there are bankrupt companies after a few years while others have failed since their first year [26] The model also does not estimate the probability of survivability, but it calculates time to company failure. Cox Proportion Hazard Model is used to analyze the variables used in assessing corporate financial distress because the technique of survival analysis is more consistent and accurate than the statistical model [26].

Previous studies using survival analyzes studied more on the impact of predictor variables on bankruptcy or financial distress. They are, for examples, in US, [27]; [25); [23); in UK, [8]; in Finland, [20]; in Australia[9]) and [13]; in Italy, [12]; in
China,[7] ; in Indonesia, [19]; [17]; and [18]. On the other hand, this research studies the functions of survival and hazard of industrial sectors listed on Indonesia stock exchange (IDX). There were 8 sectors to be analyzed: Agriculture, Basic industry \& chemicals, Consumer goods \& industry, Infrastructure, Mining, Miscellaneous, Property, and Trade, Service \& Investments. This study will extensively explore the length of time of survival and hazard of companies experiencing financial distress. Therefore, this study is expected to be able to contribute to existing financial distress literature especially in case of emerging markets like Indonesia that certainly different from developed countries. The Cox Proportional Hazard Model was utilized to explore the length of time of survival and hazard of companies experiencing financial distress bsurvival analysis technique is more consistent and accurate than statistical model [26].

\subsection{Literature Review}

Analysis survival is a statistical method for studying the occurrence and time of financial distress [1]. The first researcher applying survival analysis in the prediction of bank failure was [21]. The model used by them was based on 334 successful banks and 130 failed banks in the period of 1979-1983. Compared with discriminant analysis, the Cox model produces a lower type I error. Then, [11] applied the Cox model to Australian credit unions with the results that support the model. Reference number [24] compared the accuracy of the cox model with discriminant analysis and logit analysis. Meanwhile [10] compared the model with the logit model and results of their study showed that survival analysis provides an additional feature prediction whose ability to show the probability of companies to survive within a certain time interval. In Kansas, [28] estimated the bank failure time in the period of 1910-1928 and results of their study indicated that undercapitalization, membership in insurance deposit systems, and inefficiency had increased the level of hazard. Meanwhile reference number [14] used both cash flow and non-cash flow to test the stability of 
the model proportional hazard and there was no specific formula found in different horizons.

In the 2000s, reference number [15] combined industry business and macroeconomic variables to assess the failure of the Internet business. The study showed that macroeconomic variables are important elements. Meanwhile [27] investigated the firm's risk dimensions and attributes. They found that significant accounting covariates tended to change depending on the progress of distress stages and it also indicated the natural heterogeneity of financial distress and potential business failures. Reference number [26] compared survival analysis skills to Altman (1968) and Zmijewski (1984) and he found that half of the financial ratios used in previous studies were insignificant in predicting bankruptcy probabilities. He thought that both accounting ratios and market variables should be used to produce more accurate predictions than the existing models.

Reference number [23] reviewed the differences between time invariant and time-dependent covariates, as well as effects of covariate selection in estimating the proportional hazard model. The results suggested that the choice of time-dependence is substantial in influencing model estimates and more attention should be given to covariate choices relating to research on financial distress. In Australia, reference number [19] combined traditional financial ratios, market variables and company-specific variables with survival techniques using the Cox proportion hazard model. Result of his study showed that the Cox proportion hazard model can provide information on the probability of survival within a given timeframe and it also supports the effectiveness of financial ratios, market ratios and specific variables of companies as a predictor of financial distress. Meanwhile [13] used a comparatively new technique known as survival analysis. They also tried to combine survival analysis with discriminant analysis and logit analysis, but the results were dissatisfied. Reference number [25] investigated the association of various corporate governance attributes and financial characteristics toward the survival probability of distressed companies. Using samples of 176 distressed companies, the study found that companies replacing their $\mathrm{CEO}$ with those coming from outside companies have the possibility to experience bankruptcy twice. Furthermore, greater block holders and insider ownership levels are positively associated with the possibility of survival.

In China, reference number [7]) used micro and macroeconomic factors to investigate the effects of those factors on the financial distress in the period of 1995-2006. The results of the study showed that characteristics of the company, macroeconomic instability and institutional factors influence the hazard level of financial distress.

In Indonesia, [19] investigated corporate governance and financial ratios variables in the period of 2002-2014. The estimation method using the Cox proportional hazard regressions showed that board size, board independence, leverage, size, liquidity and return on assets have an impact on the survival likelihood of the financial distress. Reference number [17] investigated the influences of control of corruption variable and financial ratios on the probability of financial distress in 61 companies experiencing financial distress in 2002-2014 period; and [18] used a sample of $58 \mathrm{com}-$ panies experiencing financial distress and 275 health companies. Based on the two models used in the study, it was reported that independence commissioners, leverage, operating risk, size, return on asset and control of corruption become variables which consistently affect the financial distress of the company.

This study is a continuation of previous studies. By using the survival model with covariates of financial ratios, corporate governance, and political risks, this study will highlight the survival and hazard time in industry sector groups of listed Indonesian companies. With the knowledge of the hazard and survival function, the company will be helped to identify time to take anticipatory action and to implement appropriate strategies.

\subsection{Research Methods}

This study uses secondary data of financial statements of all companies listed on the Indonesia Stock Exchange (BEI) in the period of 2002-2015. Purposive sampling used with completed data criteria resulted in 336 samples of companies consisting 61 companies that experienced financial distress and 275 companies that did not experience it. Of the eight industry sectors, the companies will be grouped into three groups based on type of business whose characteristics are relatively close each other. Hence, it made the model unfit when each sector of industries was tested. This is related to the assumption in cox regression that to test the Cox Regression Coefficients a large number of samples are required (Cox, 1975). The three industrial sector groups are: (1) Infrastructure, Mining and Property, (2) Basic industry \& chemicals, Consumer industry, Miscellaneous, (3) Agriculture and Trade, Service \& Investment. This study did not consider its mathematical model, but it rather studied the hazard and survival function in the three industry groups.

The companies that are listed on the Indonesia Stock Exchange and were used in this study have been operated more than ten years. 336 samples were chosen from 537 listed companies by using purposive random sampling. The chosen companies had criteria of non-financial companies and they must have complete data during the study period of 2002-2015.

The survival analysis in this study incorporates failure time as the dependent variable in the model. So the dependent variable in this research is the length of time of the event (financial distress). Time can be in the form of year, month, week or day counted from the beginning of the study until the time when an event occurs, while the event is a designed experience that may occur [16]. In this study, time to event is the number of years started from the initial year when the company is listed on the stock until the year the company experiences the event of financial distress. Distress companies are companies with negative equity. It refers to the definition of a distressed company stating that distressed company has an inability to pay its obligations [6] and [4]. The time of the company's failure is stated in year. If the company has negative equity, then it is stated by 1 . otherwise it is expressed by 0 .

The Cox Hazard model with time independent covariates is used to view the functions of survival and hazard for each group of industrial sector of companies listed on Indonesia Stock Exchange. Hazard is the risk of an event. In this case the event refers to financial distress that is defined as a company that has negative equity [6]. Hazard also explains whether events (financial distress) will occur in a company that has survived for a certain period. The survival function shows the relationship between probabilities to survive and time that indicates the duration of the events.

The Cox Proportional hazard model is a semi-parametric model for survival analysis, which is very widely used. Refernce number [16] stated that The Cox Proportional Hazard Model (CPHM) is popular because it is a robust model so that the result will be almost closely approximated to the accuracy of the parametric model results. The proportional hazard model is presented as follows:

The Cox Proportional hazard model is a semi-parametric model for survival analysis, which is very widely used. The Cox Proportional Hazard Model (CPHM) is popular because it is a robust model so that the result will be almost closely approximated to the accuracy of the parametric model results [16]. The proportional hazard model is presented as follows:

$h_{i}(t)=h_{0}(t) \exp ^{\left(X_{1}, \square\right)}$

h1 (t) is an arbitrary unspecified baseline hazard rate that measures the effect of time on a hazard level for an individual whose variable has a zero value. $X$ represents the vector of the variable affecting hazard and $\beta$ is the vector of the coefficient. There is a deficiency in the specificity of the baseline hazard function that forms the semi-parametric model or free of distribution (Chancharat, 2008). 
The hazard model containing the exponential element as stated in formula 3 can be changed into a log form. The Regression Model can be written as follows:

$\log \mathrm{h}_{\mathrm{i}}(\mathrm{t})=\square(\mathrm{t})+\square \square \mathrm{X}_{\mathrm{i}}(\mathrm{t})+\square \square \square \square \mathrm{X}_{\mathrm{i}}(\mathrm{t})+\square \square \square \mathrm{X}_{\mathrm{i}}(\mathrm{t})$

Where $\alpha(\mathrm{t})$ is $\log \mathrm{h} 0(\mathrm{t})$ and $\mathrm{h} 0(\mathrm{t})$ is an unspecified baseline hazard rate [22].

Explanatory variables used in this study are corporate governance, financial ratios and political risk. Corporate governance variables include independent commissioner, gender diversity, and concentration ownership, while financial variables consist of financial risk, operating risk, size, liquidity risk, profitability, and market perception.

Finally The Cox proportional hazard model will be used to assess the relationship between the explanatory variable and survival time and to evaluate the probability of survival within a given time frame. The model is shown as follows:

$$
\begin{aligned}
& \log \mathrm{h}_{\mathrm{i}}(\mathrm{t}) \quad=\quad \square(\mathrm{t}) \quad+\square \square \mathrm{IC}_{\mathrm{i}}(\mathrm{t}) \quad+\square \square \square \square \operatorname{GENDIV}_{\mathrm{i}}(\mathrm{t}) \quad+ \\
& \square \text { CONOWN }_{i}(\mathrm{t})+\square \square \mathrm{FR}_{\mathrm{i}}(\mathrm{t})+\square \square \text { OPRISK }_{\mathrm{i}}(\mathrm{t})+ \\
& \mathrm{SZ}_{\mathrm{i}}(\mathrm{t})+\square_{\curvearrowleft} \mathrm{LIQ}_{\mathrm{i}}(\mathrm{t})+\square_{\triangleright} \mathrm{PROFT}_{\mathrm{i}}(\mathrm{t})+ \\
& \square \square \mathrm{MP}_{\mathrm{i}}(\mathrm{t})+\square \square \square \square \mathrm{PR}_{\mathrm{i}}(\mathrm{t})
\end{aligned}
$$

Where,

$h_{i}(t)$ : hazard of $i$ company entered in financial distress at time (Hazard at time $t$ depends on the value of each time of $t$ ).

$\alpha(\mathrm{t}): \log \mathrm{h} 0(\mathrm{t})$, where $\mathrm{h} 0(\mathrm{t})=$ hazard function for an individual having value 0 for all variables.

The hazard ratio can be seen from $e^{B j}$ indicating the effect of the change of an independent variable on its hazard function (ht) or distress probability. The hazard ratio of 1 indicates that the change of one unit of independent variable has no effect on the probability of company's distress when another variable is considered constant. The hazard ratio that is smaller (high) than 1 indicates the probability of lower (high) company distress. Each independent variable coefficient $(\beta \mathrm{j})$ estimates the hazard rate change of a particular independent variable.

\subsection{Results and Discussion}

The results of cox regression hazard model with time independent covariates found that the model is appropriate for the third type of industry sector group. It can be seen from the value of goodness of fit using chi-square. If the Chi-square value is significant then the null hypothesis is rejected and it assumes that the explanatory

\begin{tabular}{|c|c|c|c|}
\hline Group of Sector & -2 Log Likelihood & Chi-square & Sig \\
\hline IMP & 114.135 & 76.484 & .000 \\
\hline BCM & 162.993 & 102.613 & .000 \\
\hline AT & 28.509 & 66.263 & .000 \\
\hline
\end{tabular}
variable has a significant relationship with the survival time. Table 1 shows that the chi-square values are all significant at alpha $1 \%$.

Table 1: Coefisien Omnibus test of model

The estimation result using cox proportion hazard model with time varying model is shown in table 2 . The table shows that based on the statistical test of the three sectoral groups, only Political Risk with corruption as indicator is consistent variable has a significant influence $(\alpha=1 \%)$ on the probability of being companies experiencing financial distress. Control of corruption has a significant negative effect on the probability of survival. If the control of corruption rises, then the probability of survival will decrease, and vice versa. It is very useful for government as the party directly related to the control of corruption because government has a duty to do it.

An interesting thing from the IMP sector group is that financial risk measured by firm leverage shows a significant positive result ( $\alpha=5 \%$ ) on the probability of companies experiencing financial distress. It does not occur in other sectoral groups. It is known that this sectoral group has an average debt of $62.8 \%$ which indicates that this group of companies has more debt than its own capital and indicates a high risk in this group. Similarly, when it was compared to other sector groups, namely (BCM) and (AT), the averages of both groups are $53.4 \%$ and $50.5 \%$.

In the IMP sector, profitability measured by ROA also shows a significant negative result of $1 \%$. With an average ROA of $0.8 \%$, this sector has a smaller profitability than BCM and AT groups whose percentages gained $1.7 \%$ and $2.8 \%$ respectively.

Independent commissioner, in the IMP sector, has a negative effect on the company's financial distress. More independent commissioners in a company will decrease the probability of being a company experiencing financial distress. The average of IC in this sector is $42.5 \%$. It is higher than in AT group of $40.9 \%$ and the BCM group of $39.7 \%$. It indicates that the IMP sector having more Independent commissioners is capable of supervising companies well so that the companies can avoid financial distress. This percentage is in accordance with the regulation of Capital Market Supervisory Agency (Bapepam) No. I-A concerning the General Regulation of Equity Securities Listing. It is for the sake of good corporate governance. The regulation stipulates the number of independent commissioner that should be accounted at least $30 \%$ of the total commissioners.

Meanwhile, an interesting thing coming from the sector of agricultural and trade, service and investments is its operational risk that was measured by dividing the total assets by the sales. It showed a significant positive result at alpha 5\%. It explains that the higher the operational risk is, the higher the company's financial distress will be. The average operational risk in this sector is 3.33. It is greater than the BCM sector of 2.05, but it is smaller than the IMP group of 4.73. It indicates that the ability of assets to generate sales in the AT sector is relatively moderate.

Size has a significant negative effect on alpha of 5\% in both the IMP and AT sectors. It implies that the higher the size of the company is, the smaller the probability of companies experiencing financial distress will be. It means that the larger the companies are, the bigger the ability to manage their companies better is, so they can avoid financial distress. In addition, larger companies generally have ability to get external financing easier than small companies. The size of the IMP sector 6.54, while the AT sector is 6.23

Table 2: Results of Statistical Test

\begin{tabular}{|l|l|l|l|l|l|l|}
\hline \multirow{2}{*}{ Var. } & IMP) & \multicolumn{1}{|l|}{ BCM) } & AT \\
\cline { 2 - 7 } & Sig & Exp (B) & Sig & Exp (B) & Sig & Exp (B) \\
\hline IC & 0,009 & $0,000 * * *$ & 0,287 & 0,157 & 0,211 & 394,27 \\
\hline GDIV & 0,667 & 2,371 & 0,700 & 1,658 & 0,433 & 42,99 \\
\hline COWN & 0,203 & 0,312 & 0,424 & 2,304 & 0,962 & 2530,79 \\
\hline FR & 0,010 & $2,539 * *$ & 0,468 & 1,230 & 0,346 & 154,62 \\
\hline OPRISK & 0,741 & 1,102 & 0,738 & 1,041 & 0,044 & $2,50 * *$ \\
\hline SZ & 0,017 & $0,418 * *$ & 0,411 & 0,724 & 0,004 & $7,14 * *$ \\
\hline LIQ & 0,880 & 1,101 & 0,389 & 1,099 & 0,734 & 1,35 \\
\hline PROFT & 0,008 & $0,002 * * *$ & 0,158 & 0,002 & 0,865 & 0,00 \\
\hline MP & 0,350 & 0,836 & 0,450 & 1,997 & 0,974 & 47039,19 \\
\hline PR & $\mathbf{0 , 0 0 0}$ & $\mathbf{0 . 0 0 0} * * *$ & $\mathbf{0 , 0 0 0}$ & $\mathbf{0 , 0 0 0} * * *$ & $\mathbf{0 , 0 0 0}$ & $\mathbf{0 , 0 0 0} * * *$ \\
\hline T-COV & 0.120 & 0,988 & 0,859 & 1,003 & 0,138 & 0,76 \\
\hline
\end{tabular}

mation results

\subsection{The Industrial Group of AT Sectors}

In the AT industrial group, the probability of companies experiencing financial distress after 12.5 years is very small. Conversely, according to the image hazard function, the probability of not experiencing the financial distress after 12.5 years is very large. 

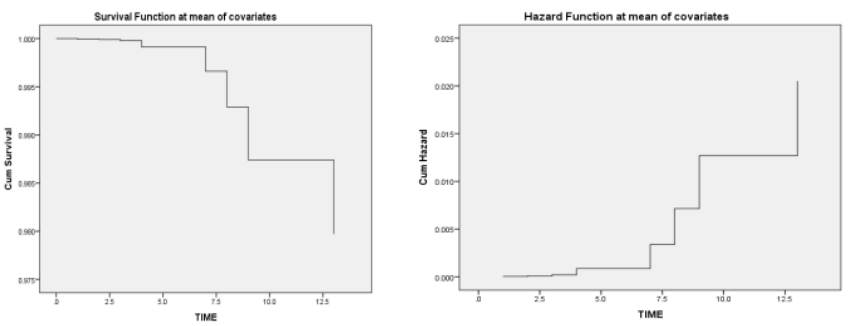

Fig. 1: The Function of Survival and Hazard of AT industrial group

\subsection{The Industrial Group of IMP sectors}

In the IMP industrial group, the probability of companies experiencing financial distress after 12 years is very small. It means that if the company can exist up to 12 years, it can be said that the company can survive (the company does not experience financial distress). In contrast to the image of hazard function, the probability of not experiencing financial distress after 12 years is very large.
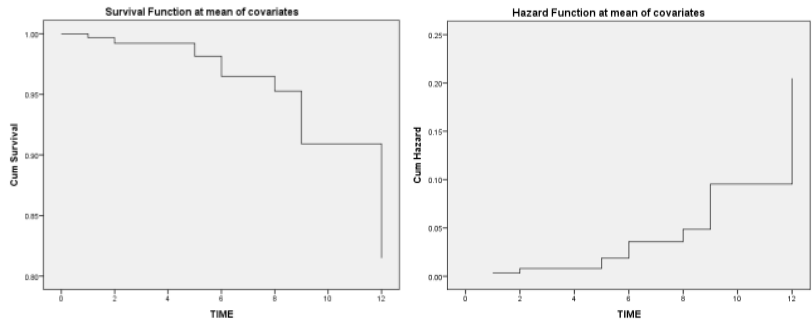

Fig. 2: The Function of Survival and Hazard of IMP industrial group

\subsection{The Industrial Group of BCM sectors}

The probability of experiencing financial distress after 10.5 years in the industrial group of BCM sectors is very small. It means that after 10.5 years the company is very unlikely to experience financial distress. Conversely, based on the hazard function image, the probability of not experiencing financial distress after 10.5 years is very large.
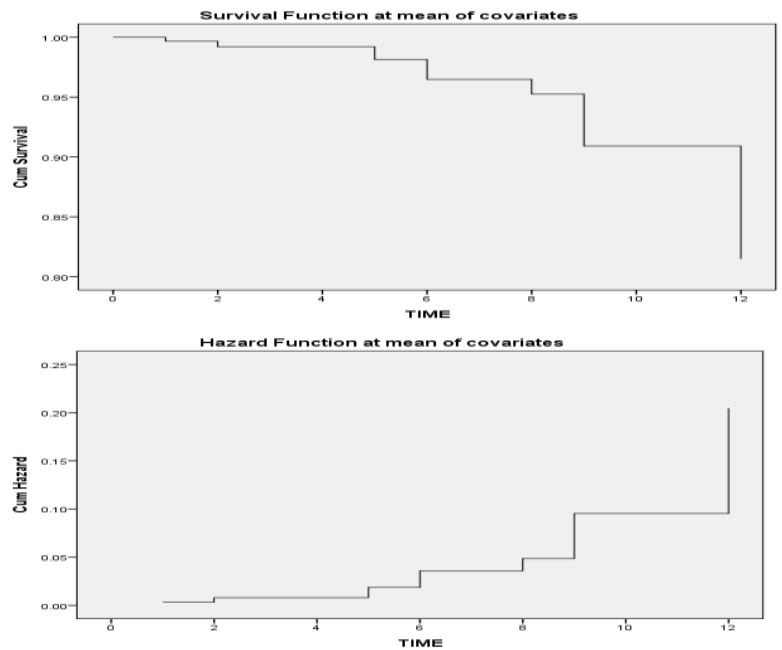

Fig. 3: The Function of Survival and Hazard of BCM industrial group.

In accordance with Figure 1, 2, and 3, it appears that the BCM industrial group has the shortest survival time of 10.5 years. This industrial group consists of Basic industry \& chemicals, Consumer industry, Miscellaneous. This is supposedly because these groups produce goods that are relatively needed by consumers. Therefore, such companies can survive more in deteriorating economic conditions. However, it is somewhat different from other industrial groups. The agricultural and trade sectors have the longest survival time of 12.5 years.

The survival time can be used as an early warning for companies to take preventive actions to avoid the more severe problems of financial distress. By recognizing the time of survival, then appropriate strategies can be prepared and the company can survive in a business that is increasingly full of competition. The companies that are able to maintain their sustainability are those being able to overcome all difficulties and to survive with all their own capabilities.

\section{Conclusion}

In Indonesia, each industrial group has different survival time but on average companies have a twelve-year survival time. A sustain company is a company that can survive in running its activity. Survival time can be used as a basis to determine the appropriate strategies as preventive actions. In all observed sectors (IMP, BCM \& AT), the control of corruption has a negative effect on the company's financial distress. It shows that for a developing country like Indonesia, this variable is still a determinant for financial distress problems experienced by companies. Therefore, cooperation from both the government and the bureaucrat is needed to eliminate the possibility of corruption.

Companies in Indonesia have a greater number of independent commissioners than required by the government. The condition indicates that companies in Indonesia, on average, have applied Good Corporate Governance to their control function by involving independent commissioners who come from the outside companies as ruled in the existing regulations. In addition to the control of corruption, in the IMP sector, the Independent Commissioner, Size, and Profitability negatively affect the company's financial distress, while leverage has a positive effect. Meanwhile, in the sector of AT the operational risk positively affects the financial distress of companies.

Further research using survival analysis still can be conducted especially relating to the sectors of financial and insurance. Moreover, research can also be done in small, medium and large enterprises, as well as on state-owned enterprises.

\section{Acknowledgment}

This paper is one of the outputs of the Fundamental Grants of the Directorate General of Higher Education (Dikti) of 2017 funding

\section{References}

[1] Allison, P.D., "Survival Analysis Using the SAS System," SAS Institute, Cary, NC., 1995.

[2] Altman. E.I. 1984. A further empirical investigation of the bankruptcy cost question, Journal of Finance, 39(4), 1984, pp.10671089.

[3] Altman. E.I., "Financial Ratios, discriminant analysis and the prediction of corporate bankruptcy," Journal of Finance, 23(4), 1968 pp.589-609.

[4] Andrade. E. I., \& S. Kaplan, "How costly is financial (not economic) Distress? Evidence from Highly Leveraged Transactions that became distress," The Journal of Finance, 53 (5), 1968, pp.11431493.

[5] Argenti. J., "Corporate Collapse the causes and symptoms," McGraw Hill, London. 1976.

[6] Beaver, W.H., "Financial Ratio as Predictor of Failure, Empirical Research in accounting: Selected Studies," Journal of Accounting Research, 5,1966. Pp.71-111

[7] Bhattacharjee, A. \& J. Han, "Financial distress of Chinese firms: Microeconomic, macroeconomic and institutional influences. China Economic Review, 30, 2014, pp.244-262. DOI: 10.1016/j.chieco.2014.07.007

[8] Bhattacharjee, A., C. Higgson, S. Holly, \& P. Kattuman, "Macroeconomic condition and business exit: Determinant of failure and 
acquisition of UK firms," Working Paper, University of Cambridge, Cambridge, UK. 2004.

[9] Chancharat, Nongnit., "An empirical analysis of financially distress Australian companies: the application of survival analysis," $\mathrm{PhD}$ Thesis, School of accounting and Finance, University of Wollongong. 2008. http://ro.uow.edu.au/thesis/401, Accesed at November, 2013.

[10] Chen, K.C.W., \& C.W.J Lee, "Financial Ratio and corporate endurance: A case of the gas and oil industry," Contemporary Accounting Research, 9(2), 1993, pp.667-694.

[11] Crapp, H.R. \& M. Stevenson, M, "Development of a method to assess the relevant variables and the probability of financial distress," Australian Journal of Management, 12(2), 1987, pp.221-236.

[12] Donato, Francesca \& Luciano Nieddu, "A quantitative analysis of trigger factors influencing companies failure in Italy," European Scientific Journal, April, Vol 10, No. 10. 2014. Pp.1-16.

[13] Gepp, Adrian \& Kuldep Kumar, "The role of survival analysis in financial distress prediction," International Research Journal of Finance and Economics, Issues 16, 2008, pp.13-34.

[14] Henebry, Kathleen L., "A test of the Temporal Stability of Proportional Hazards Models for predicting Bank failure," Journal of Financial and Strategic Decisions. Volume 10 Number 3, 1997, pp.111.

[15] Kauffman, R. \& B. Wang, "Duration of the digital economy: Empirical bases for the survival of internet firms," 36th International Conference on system Science, Hawaii. 2003.

[16] Kleinbaum, David G., \& Mitchel Klein., "Survival Analysis, A Self-Learning Text," Springer, Third Edition. 2012.

[17] Kristanti, F.T. \& N. Effendy, "A Survival Analysis of Indonesian Distressed Company Using Cox Hazard Model," Int. Journal of Economics and Management. 11 (S1), 2017, pp.157 - 169.

[18] Kristanti, F.T. \& Aldri Herwany, "Corporate Governance, Financial Ratios, Political Risk and Financial Distress: A Survival Analysis," Acc. Fin. Review. 2 (2), 2017, pp.26 - 34.

[19] Kristanti, Farida Titik, Nurry Effendi, Aldrin Herwany, \& Erie Febrian," Advanced Science Letters, Vol 22, Number 12, December 2016, pp. 4326-4329(4).

[20] Laitinen. Erkki K., "Survival analysis and financial distress prediction,: Finish evidence," Review of Accounting \& Finance, 4(4), 2005, pp.76-90.

[21] Lane, W.R., S.W. Looney \& J.W. Wansley, "An application of the cox proportional hazards model to bank failure," Journal of Banking and Finance, 10(4), 1986, pp.511-531.

[22] LeClere, M.J., "The occurrence and timing of events, Survival analysis applied to the study of financial distress," Journal of Accounting Literatur, 19, 2000, pp.158-189.

[23] LeClere, M.J., "Time-dependent and time-invariant covariates within a proportional hazard models: A Financial distress applications," Review of Accounting and Finance, 4(4), 2005, pp.91-109.

[24] Louma, M. \& E.K.Laitinen, "Survival analysis as atool for company failure prediction," Omega, The International Journal of Management Science. 19(6), 1991. 673-678.

[25] Parker, Susan., Peters Gary F. \& Howard Turetsky, "Corporate Governance and corporate failure: a survival analysis," Corporate Governance, 2(2), 2011, pp.4-12.

[26] Shumway, T., "Forecasting Bankruptcy More Accurately: A Simple Hazard Model," The Journal of Business, 74(1), 2001, pp.101124.

[27] Turetsky, S. \& R.A. McEwen, "An empirical investigations of firm longevity: A model of the exante predictors of financial distress," Review of Quantitative Finance and Accounting, 16(4), 2001.pp

[28] Wheelock, D.C. \& P.W. Wilson, "Why do banks disappear? The determinants of US bank failure and acquicitions," Review of Economics and Statistics, 77(4), 2000, pp.689-700.

[29] Zmijewsky, M.E., "Methodological issues related to the estimation of financial distress prediction models," Journal of Accounting Research, Supplement to Vol. 22, 1984, pp.59-82. 